\title{
MicroRNAs in Metastasis and the Tumour Microenvironment
}

\author{
Carla Solé ${ }^{1, *(\mathbb{D})}$ and Charles Henderson Lawrie ${ }^{1,2,3}$ (D) \\ 1 Molecular Oncology Group, Biodonostia Research Institute, 20014 San Sebastian, Spain; \\ charles.lawrie@biodonostia.org \\ IKERBASQUE, Basque Foundation for Science, 48009 Bilbao, Spain \\ 3 Radcliffe Department of Medicine, University of Oxford, Oxford OX4 3DU, UK \\ * Correspondence: Carla.sole@biodonostia.org
}

\section{check for}

updates

Citation: Solé, C.; Lawrie, C.H MicroRNAs in Metastasis and the Tumour Microenvironment. Int. J. Mol. Sci. 2021, 22, 4859. https:// doi.org/10.3390/ijms22094859

Academic Editor: Young-Ho Ahn

Received: 10 April 2021

Accepted: 30 April 2021

Published: 4 May 2021

Publisher's Note: MDPI stays neutral with regard to jurisdictional claims in published maps and institutional affiliations.

Copyright: (c) 2021 by the authors. Licensee MDPI, Basel, Switzerland. This article is an open access article distributed under the terms and conditions of the Creative Commons Attribution (CC BY) license (https:// creativecommons.org/licenses/by/ $4.0 /)$.

\begin{abstract}
Metastasis is the process whereby cancer cells migrate from the primary tumour site to colonise the surrounding or distant tissue or organ. Metastasis is the primary cause of cancerrelated mortality and approximately half of all cancer patients present at diagnosis with some form of metastasis. Consequently, there is a clear need to better understand metastasis in order to develop new tools to combat this process. MicroRNAs (miRNAs) regulate gene expression and play an important role in cancer development and progression including in the metastatic process. Particularly important are the roles that miRNAs play in the interaction between tumour cells and non-tumoral cells of the tumour microenvironment (TME), a process mediated largely by circulating miRNAs contained primarily in extracellular vesicles (EVs). In this review, we outline the accumulating evidence for the importance of miRNAs in the communication between tumour cells and the cells of the TME in the context of the pre-metastatic and metastatic niche.
\end{abstract}

Keywords: tumour microenvironment; miRNAs; metastasis

\section{Introduction}

Cancer metastasis, the spread of tumour cells from the primary tumour site, has been reported to account for approximately $67-90 \%$ of cancer-related deaths. Approximately half of all cancer patients present with metastasis at the time of diagnosis [1-3]. Metastasis is a multistep process, which starts when tumour cells detach from the primary tumour mass, intravasate into lymphatic and circulatory systems to become circulating tumour cells (CTCs), extravasate to leave the circulation, invade and proliferate in a new niche of a distant tissue/organ to form a new tumour [4]. The metastatic process is very inefficient since from the $0.2 \%$ of CTCs that survive their time in circulation, only those cells that are the first to reach permissive target organs and are then able to colonize those tissues can initiate metastatic tumour growth [5].

It is well-known that cancer initiation and progression, as well as metastasis, not only depends on tumour cells themselves, but also on the cells of the tumour microenvironment (TME) [6-8]. The major components of the TME apart from tumour cells include cancerassociated fibroblasts (CAFs), endothelial cells and immune cells, in addition to other components such as the extracellular matrix [9-11]. Hypoxia, cellular oxygen deprivation, is an important factor that drives many aspects of metastasis [12,13], including the initiation of the epithelial-mesenchymal transition (EMT) process that changes the phenotype of tumour cells allowing them to escape from the matrix of the primary tumour [14]. In addition to hypoxia, the interaction between tumour cells and the TME induces a wide range of biological events that are necessary for metastasis including proliferation, immunosuppression and angiogenesis [15-17]. Many of these processes are regulated by microRNAs (miRNAs) and are the subject of this review. In addition to the direct control of metastasis by miRNAs, it has been recently shown that they can regulate the metastatic process by acting as mediators of intercellular communication between tumour cells and cells of the TME $[18,19]$. 
MiRNAs are a class of small (19-25 nucleotides) non-coding single-strand RNAs. Since their initial discovery in Caenorhabditis elegans [20], miRNAs have been demonstrated to play key roles in many, if not all, physiological cellular functions by regulating target genes through primarily negative post-transcriptional regulation of gene expression [21-23]. A single miRNA is capable of targeting many genes and, conversely, a single gene can be targeted by many miRNAs leading to a complex regulatory network that encompasses more than $60 \%$ of human genes [24]. In addition to their importance under physiological conditions, miRNAs are ubiquitously deregulated in cancer and can act as tumour-promoting miRNAs (oncomiRNAs and metastamiRNAs) targeting messenger RNAs (mRNAs) coding for proteins that act as tumour suppressors or as tumour suppressor miRNAs targeting mRNAs coding for proteins with oncogenic properties [25].

In 2007, two separate reports released in parallel first described the association between miRNAs and metastasis. Ma et al. demonstrated that miR-10b could promote breast cancer metastasis in vitro and in vivo through targeting of the HOXD10 (Homeobox D10) gene [26], whilst Yu et al. demonstrated that let-7 can act as a metastasis suppressor miRNA through targeting of H-RAS and HMGA2 (High Mobility Group AT-Hook 2), leading to a reduction in proliferation, mammosphere formation and metastatic potential, including in breast cancer [27]. Subsequently, many miRNAs have been identified that are associated with metastasis or with associated pathways, such as migration and invasion [28].

In this review, we considered the role of miRNAs in the cross-talk between tumour and non-tumoral TME cells to promote metastasis. Further understanding of these processes could be useful to develop new treatments for metastatic cancer patients and identify new biomarkers with the ability to improve the management and follow-up strategies for cancer patients.

\section{Biogenesis and Delivery of miRNAs}

MiRNA biogenesis starts with the transcription of pri-miRNA sequences from the DNA, with approximately half of miRNAs encoded within intragenic sequences, mainly from introns with the remainder transcribed from intergenic regions and regulated by specific promoter regions [29]. Approximately half of pri-miRNAs encode for multiple miRNAs in a cluster. MiRNA biogenesis can follow either canonical or non-canonical pathways [30]. The canonical miRNA biosynthetic pathway starts with transcription of the pri-miRNA sequence by RNA polymerase II/III; then, RNase-III endonucleases Drosha in concert with the DGCR8 (DiGeorge syndrome critical region 8) cofactor cleave pri-miRNA to form a hairpin pre-miRNA structure [31]. DGCR8 acts to recognize motifs within the pri-miRNA, such as N6-methyladenylated GGAC, while Drosha cleaves pri-miRNA at the base of the structure [31,32]. The resultant pri-miRNA hairpin structure is exported to the cytoplasm by the exportin-5 (XPO5)/RanGTP complex [33], where it is processed by the RNAse III endonuclease Dicer, which removes the terminal loop of the pre-miRNA structure, resulting in a mature miRNA duplex (Figure 1) [34]. The duplex separates into single-strand effector miRNAs which are loaded into the Argonaute (AGO) protein to form the RNA-induced silencing complex (RISC) that regulates expression of target genes through binding of the miRNA to (primarily) the $3^{\prime}$ UTR region of mRNA [35,36], although instances exist whereby miRNAs can bind to the 5'UTR region, promoter regions and even the coding sequence [37-39]. Gene regulation by miRNAs primarily occurs at the post-transcriptional stage and many mechanisms have been described, the majority of which act negatively although positive regulation has also been described [40]. 


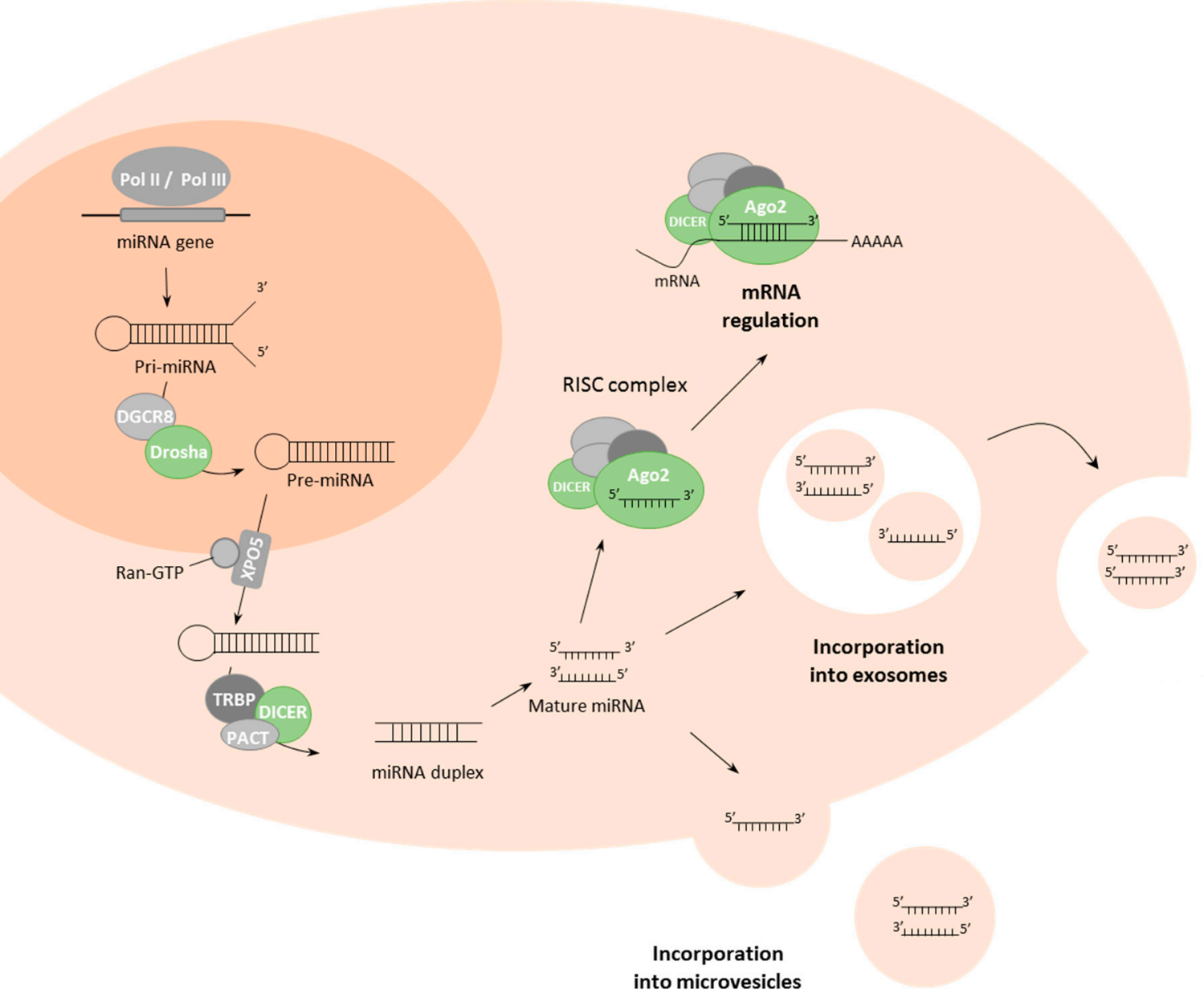

Figure 1. MiRNA biogenesis and its localization. MiRNAs are processed by polymerase II/III to form a pri-miRNA, which is processed by DGCR8 and Drosha in the nucleus. MiRNAs leave the nucleus through interaction with XPO5; in the cytoplasm, miRNAs are processed by a group of proteins, the most important being the RNAse III endonuclease Dicer, resulting in mature miRNAs. These miRNAs can be added to the RISC complex to regulate mRNA expression or can be incorporated into extracellular vesicles (exosomes and microvesicles) to reach other cells in the tumour microenvironment or cells in the premetastatic niche. Pol II / Pol III, polymerase II and III; DGCR8, DiGeorge syndrome critical region 8; XPO5, exportin-5; TRBP, HIV TAR RNA-binding protein; PACT, protein activator of PKR; RISC complex, RNA-induced silencing complex; Ago2, Argonaute 2; miRNA, microRNA; mRNA, messenger RNA.

In addition to their role within the cells, miRNAs can act extracellularly leading to great interest in their role as cellular messengers [41]. The most intensely studied form of extracellular miRNAs involved in cell-to-cell communication is extracellular vesicles (EVs), although it should be noted that some controversy remains as to the relative importance of this format with some authors suggesting that most extracellular miRNAs exist in the free form bound to proteins or lipids [42,43]. EVs consist in a lipid bilayer membrane containing lipids, proteins and nucleic acids (including miRNAs) derived from the original cell, which protected their content from enzymatic degradation during transit through the extracellular microenvironment [44]. EVs can be classified mainly into microvesicles (100-1000 nm) and exosomes (50-100 nm) [45]; during the metastatic process, it has been described that they participate in communication between cells and in the preparation of the premetastatic niche [46-48]. Extracellular miRNAs are taken up by receptor cells; this internalization can occur by different mechanisms, such as direct membrane fusion, endocytosis and receptor binding, which could trigger a downstream cascade or produce internalization of the vesicle (Figure 2) $[49,50]$. Several miRNAs have been described to 
participate in the communication between tumour cells and between tumour cells and tumour stromal cells and regulate metastasis (Table 1).

\section{DONOR CELL}

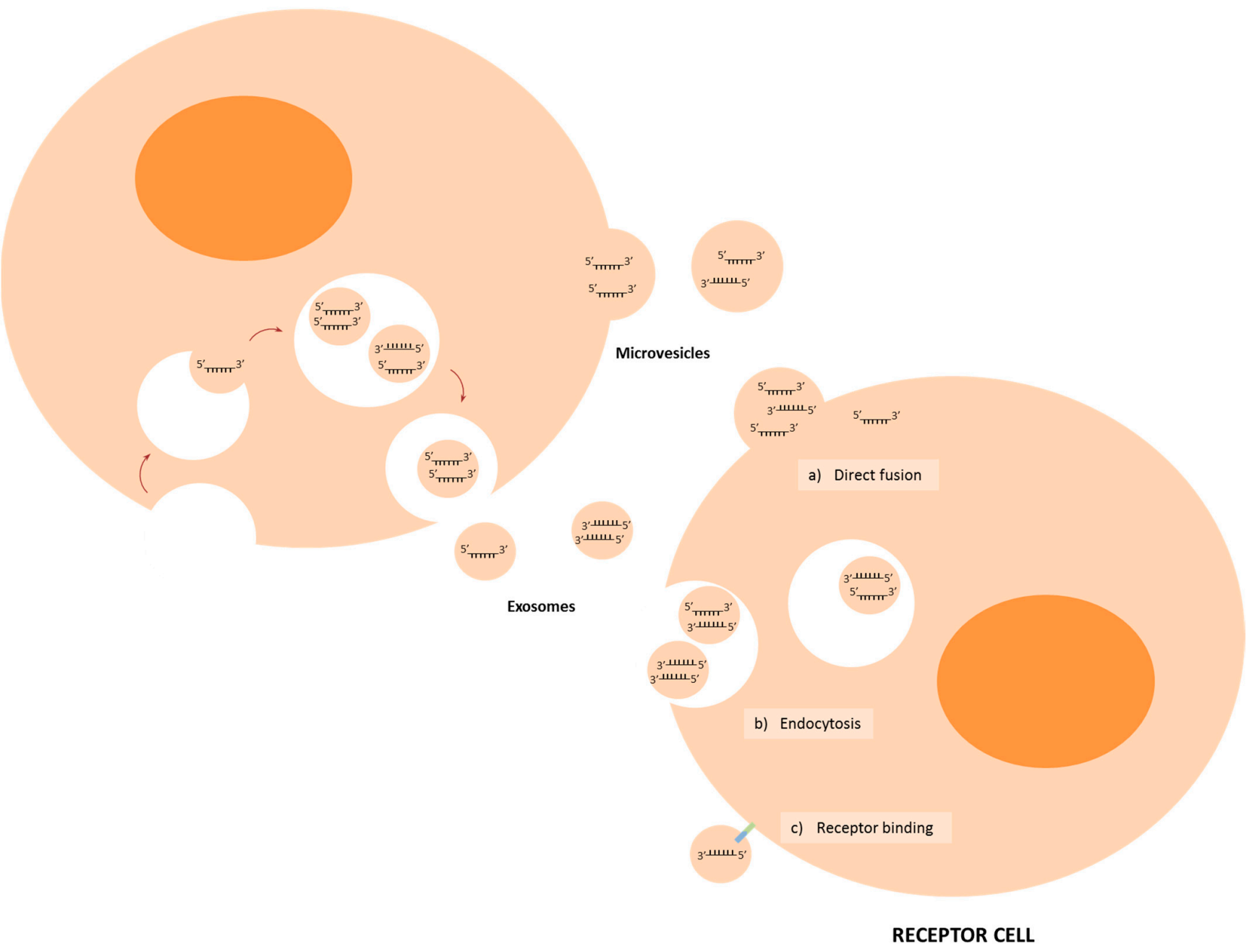

Figure 2. Cross-talk pathways between cells in the tumour microenvironment. It has been described that donor cells secrete miRNAs mainly inside exosomes and microvesicles; these could reach and enter the receptor cell through three different mechanisms: direct fusion, endocytosis and receptor binding. In the recipient cells, these miRNAs perform their function in the case of cancer favouring tumour growth and/or metastasis.

\section{MiRNAs in Intercellular Communication in the TME}

Several miRNAs have been described to participate in the communication between tumour cells and cells of the TME, such as fibroblasts, endothelial cells or immune cells, among others; and several of them regulate expression of genes that are involved in the metastasis process (Figure 3). 


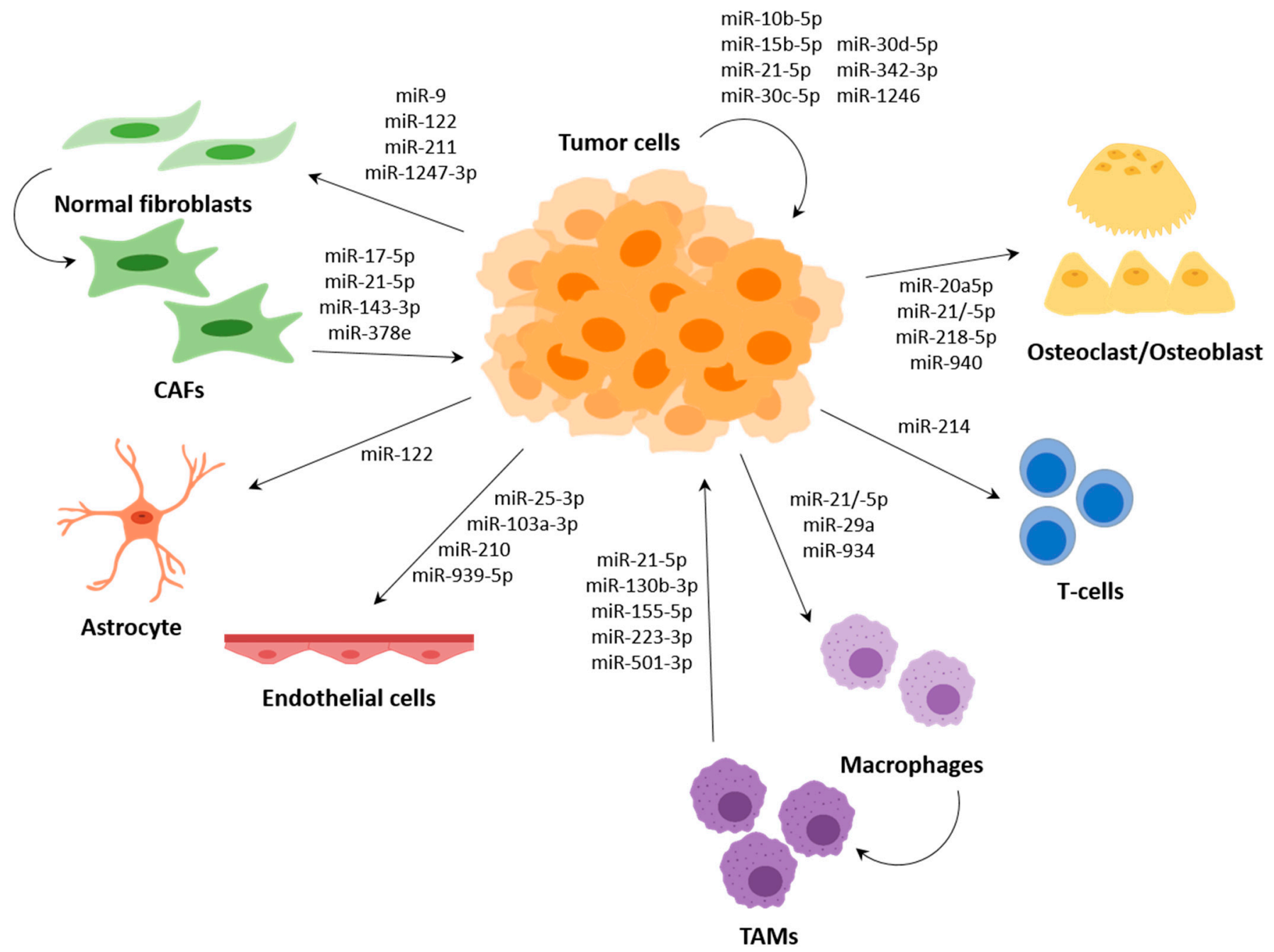

Figure 3. Diagram of the metastasis miRNAs involved in communication between cells in the tumour microenvironment. Tumour cells and cells from the tumour microenvironment, such as fibroblasts, astrocytes, endothelial cells, macrophages, $\mathrm{T}$ cells, osteoclasts and osteoblasts, communicate via miRNAs, mainly incorporated into EVs. Tumour cells communicate with each other in the tumour microenvironment to increase its malignancy. Moreover, communication between tumour cells and fibroblasts is mainly related with the switch to the CAF phenotype, while communication between CAFs and tumour cells increase tumour cell mobility and metastasis, similar to what occurs in macrophages where transformation to TAMs is promoted. Cross-talk with astrocytes is related to preparing a metastatic niche in the brain as osteoclasts and osteoblasts which are related with bone metastasis. Finally, communication with endothelial cells is more related with angiogenesis and inflammation, which at the end promote metastasis. EVs, extracellular vesicles; CAFs, cancer-associated fibroblasts; TAMs, tumour-associated macrophages.

\subsection{Surrounding Tumour Cells and Premetastasis Niche Formation}

The acidic microenvironment of the TME has been shown to promote the release of EVs and has been associated with tumour progression and metastasis. In glioblastoma, glioma stem cells in acidic microenvironment secrete EVs with MAPK/ERK (mitogenactivated protein kinase/Ras-dependent extracellular signal-regulated kinase)-targeting miRNAs that produce oncogenic reprogramming of the microenvironment, promoting local tumour infiltration [51]. In hepatocellular carcinoma (HCC), exosomal secretion of miR-21-5p and miR-10b-5p induced by acidic microenvironment promote proliferation, migration and invasion of recipient HCC cells [52].

In the TME, cancer stem cells (CSCs) have been found to be important in tumour maintenance and metastasis [53]. It is generally believed that only a subpopulation of tumour cells are able to initiate metastasis, defined as CSCs [54,55]. Moreover, CSCs also 
exhibit other traits that drive metastasis, including mobility, invasiveness and apoptotic resistance [56-58]. In particular, cross-talk between CSCs and tumour cells via miRNAs has been described in clear cell renal cell carcinoma (ccRCC) where exosomal miR-19b$3 p$ secreted by CSCs were demonstrated to be effectively transferred to tumour cells and to induce EMT in those cells via the targeting of PTEN (phosphatase and tensin homolog) [59]. In addition, highly metastatic cells from oral squamous cell carcinoma (OSCC) were observed to secrete miR-342-3p and miR-1246 packaged in exosomes, which were transferred to poorly metastatic cells and shown to promote cell motility and invasive ability of these cells [60].

In distant metastasis, bone is a preferred site for many types of cancer, such as breast and prostate cancer. Metastatic bone lesions are classified as osteoblastic or osteolytic lesions; these are induced by an imbalance between bone formation (osteoblasts) and resorption (osteoclasts) which can be produced by cancer-secreted miRNA in bone microenvironment [61]. Breast cancer is related with osteolytic bone metastasis and some of the secreted miRNAs described with this phenomenon are miR-20a-5p, miR-218 and miR-21 [62-64]. High expression of miR-20a-5p has been found in breast tumour cells and also in their exosomes; overexpression in breast tumour cells promotes migration and invasion, while exosomal miR-20a-5p is transferred to bone marrow macrophages and facilitates osteoclastogenesis [62]. Furthermore, in breast cancer, miR-218-5p has been described upregulated in blood samples from patients with bone metastasis; further analysis of this miRNA showed that EV-associated miR-218-5p can downregulate type I collagen expression and deposition by osteoclasts thereby decreasing bone formation and mediating bone niche adaptation, promoting bone metastasis [63]. MiR-21 has also been described to promote differentiation and activation of osteoclasts in breast cancer and lung cancer, reducing both bone density and promoting bone metastasis $[64,65]$. On the other hand, prostate cancer is related with osteoblastic bone metastasis. Hashimoto et al. described eight highly expressed exosomal miRNAs in prostate cells that correlated with the osteoblastic phenotype including EV-associated miR-940 that was demonstrated to promote osteogenic differentiation of mesenchymal stem cells (MSCs) in bone microenvironment through targeting of ARHGAP1 (Rho GTPase-activating protein 1) and FAM134A (family with sequence similarity 134, member A) [66].

Finally, in the metastatic niche, glucose availability plays an important role in cellular colonization and metastatic formation. In breast cancer, the EV-mediated transfer of miR122 from tumour cells was shown to reduce glucose uptake by recipient lung fibroblasts and brain astrocytes both in vitro and in vivo via targeting of PKM2 (pyruvate kinase M2) and GLUT1 (glucose transporter 1) resulting in promotion of colonization and metastasis [67].

\subsection{Cancer-Associated Fibroblasts (CAFs)}

Cancer-associated fibroblasts (CAFs) are a group of activated fibroblasts in the TME with high heterogeneity and plasticity that represent a major component of the tumour stroma through production of many of the molecules that make up the extracellular matrix, including cytokines, chemokines and growth factors. CAFs play an important role in tumour progression and metastasis in many cancers, including breast and colorectal cancers, through multiple pathways. CAFs promote survival, growth, invasiveness and angiogenesis of cancer cells by secretion of growth factors, transporting molecules through EVs, or can remodel the extracellular matrix, which is crucial for cancer cell invasiveness [68].

The origin of CAFs is still poorly understood and it has been suggested that tumour cells can promote the transformation of normal fibroblasts into CAFs through EV-associated miRNAs [69]. For example, in HCC, high-metastatic cells have been shown to secrete exosomal miR-1247-3p, which in turn was demonstrated to be taken up by fibroblasts resulting in their activation, and the resultant CAFs secreted proinflammatory cytokines and promoted tumour stemness, EMT, chemoresistance and lung metastasis [70]. In breast cancer, tumour-secreted EV-associated miR-9 was demonstrated to be taken up by normal recipient fibroblasts enhancing the switch to CAF phenotype and increasing cell motility [71]. In 
melanoma in situ, specific pigment vesicles (melanosomes) were demonstrated to transport miRNAs to fibroblasts resulting in changes to receptor fibroblasts, including increased proliferation, invasion, migration and proinflammatory gene expression, thereby enhancing invasion and formation of the dermal tumour niche [72].

The contrary situation has also been described with CAFs also able to secrete EVassociated miRNAs to recipient tumour cells [73,74]. For example, in breast cancer, CAF exosomes contained high levels of miR-21-5p, miR-378e and miR-143-3p, which could be transferred to recipient tumour cells, which exhibited increased mammosphere formation capacity, EMT marker production and anchorage-independent cell growth [73]. In colorectal cancer (CRC), miR-17-5p was shown to be highly expressed in CAF exosomes that were transferred to tumour cells leading to targeting of RUNX3 (RUNX family transcription factor 3) which was demonstrated to effect the interaction with MYC and subsequent binding to the TGF- $\beta 1$ (transforming growth factor beta 1 ) promoter leading to pathway activation and tumour progression [74].

In addition to intercellular communication by miRNAs between tumour cells and fibroblasts, miRNA expression itself within tumour fibroblasts can be affected by their interaction with tumour cells. Mitra et al. found three differentially expressed miRNAs in ovarian CAFs, two of them downregulated (miR-31 and miR-214) and one upregulated (miR-155), compared with normal fibroblasts which were demonstrated to induce the conversion of normal fibroblasts into CAFs [75]. In breast cancer, miR-200s and miR-205 have been described to mediate reprogramming of normal fibroblasts into CAFs and trigger invasion and angiogenesis, respectively $[76,77]$.

\subsection{Endothelial Cells}

During metastasis, the disruption of the endothelial cell tight junctions and recruitment of new blood vessels called angiogenesis is essential for tumour progression [78,79]. Exosomal miR-939-5p in breast cancer and exosomal miR-103a-3p in HCC have been described to be transferred from tumour cells to endothelial cells and directly target vascular endothelial (VE)-cadherin, leading to the destruction of tight junctions thereby facilitating the transendothelial migration of tumour cells by disruption of endothelial junction integrity $[80,81]$. Moreover, expression of serum miR-103a-3p in HCC patients has been associated with higher metastasis potential [81].

The protein ZO-1 (zonula occludens-1) is a component of the tight junction, which can also be targeted by exosomal miRNAs. For example, miR-25-3p in CRC and miR-105 in breast cancer both target ZO-1 leading to the promotion of vascular permeability and metastasis [82,83]. Exosomal-associated miR-105 in breast cancer targets directly ZO-1 in endothelial cells [83], while regulation of ZO-1 by exosomal miR-25-3p occurs indirectly, as miR-25-3p targets KLF2 and KLF4 (Krüppel-like factors 2 and 4) in endothelial cells, regulating expression of ZO-1, VEGFR2 (vascular endothelial growth factor), occludin and claudin-5 [82]. Moreover, circulating expression of miR-25-3p is significantly higher in CRC patients with metastasis [82], while miR-105 can be detected in circulation at the premetastatic stage [83].

Increased levels of extracellular miR-210, an important regulator of angiogenesis, was secreted by breast cancer metastatic cells and transferred to endothelial cells, which resulted in enhanced angiogenesis due to increased levels of nSMase2 (neutral sphingomyelinase 2) expression [84]. This miRNA was also secreted by hypoxic breast tumour cells to the neighbouring TME, including endothelial cells, where it targeted vascular remodelling target genes, such as ephrin A3 and PTP1B (protein tyrosine phosphatase non-receptor type 1), resulting in promoted angiogenesis [85]. Exosomal miR-210-3p secreted by HCC tumour cells and delivered also in endothelial cells targeting SMAD4 (SMAD family member 4) and STAT6 (signal transducer and activator of transcription 6) resulted in enhanced angiogenesis [86]. 


\subsection{Immune System Modulation by miRNAs}

Macrophages are the most abundant infiltrative immune cells present in and around tumours and play a critical role in inflammation [87]. Macrophages are known to polarize, depending on different stimuli, to the M1 phenotype with anti-tumour activity or to the M2 phenotype with pro-tumoral activity. Tumour-associated macrophages (TAMs), which are considered to be M2-like, support different aspects of tumour development, including tumour formation, growth and metastasis [88,89].

The premetastatic inflammatory response generated by TAMs leads to tumour growth and metastasis. MiR-21 and miR-29 secreted by lung tumour cells target TLR8 (toll-like receptor 8) within intracellular endosomes leading to induction of NF- $\mathrm{KB}$ (nuclear factor kappa-light-chain-enhancer of activated B cells) and NF-KB-mediated secretion of the proinflammatory cytokines TNF- $\alpha$ (tumour necrosis factor alpha) and IL-6 (interleukin-6) [90]. In bladder cancer, macrophages take up exosomal miR-21-5p from tumour cells leading to promotion of M2 polarization and enhanced migration and invasion of tumour cells [91]. Both CRC cell-derived exosomal miR-934 and hypoxic pancreatic cell-derived exosomal miR-301a-3p were demonstrated to activate PI3K/AKT (phosphatidylinositol 3-kinase/protein kinase B) signalling pathway and enhance metastatic capacity of tumour cells through PTEN targeting [92,93]. PTEN also plays an important role in the regulation of $\mathrm{T}$ cells, and it has been demonstrated that $\mathrm{EV}$-associated miR-214 from a range of tumour cells including breast cancer, hepatocellular carcinoma, non-small-cell lung cancer (NSCLC) or pancreatic cancer could transfer to T cells leading to downregulation of PTEN and promoting T-reg (regulatory T cells) expansion and IL-10 (interleukin-10) secretion, which in turn promotes tumour growth and enhanced immune suppression in vivo [94].

MicroRNAs have also been shown to be involved in the recruitment of immune cells to the TME, but rather than through the transfer of miRNAs from tumour cells to immune cells, this occurs through the secretion of attractant molecules. For example, both miR-149 in triple-negative breast cancer (TNBC) and miR-148b in HCC have been demonstrated to target colony-stimulating factor-1 (CSF-1) miRNAs [95,96]. In TNBC, downregulation of miR-149 promoted lung metastasis by enhancing CSF1-dependent recruitment and M2 polarization of macrophages, which also correlated with macrophage infiltration and reduced survival in patient samples [95]. Downregulation of miR-148b in HCC patients correlated positively with recurrence, metastasis and poor prognosis. Moreover, in vitro and in vivo metastatic HCC cells showed decreased levels of miR-148b that correlated with increased CSF1, which promoted HCC growth and metastasis through CSF1/CSF1R (colony-stimulating factor-1 receptor)-mediated TAM infiltration [96]. Similarly, miR-561$5 p$, which directly target chemokine (C-X3-C motif) ligand 1 (CX3CL1), in metastatic HCC downregulated CX3CL1 leading to low infiltration of CX3CR1 (CX3C chemokine receptor 1)-positive NK cells and resulting in promoted tumorigenesis and metastasis [97].

Moreover, it has been described that TAMs in the TME can release extracellular vesicles with miRNAs, and these can be transferred to tumour cells, generally promoting migration, invasion and metastasis. In CRC, exosomal miR-21-5p and miR-155-5p from macrophages directly target the BRG1 coding gene in tumour cells; this gene is a key factor promoting metastasis [98]. Another example is macrophage-derived EVs in gastric cancer (GC), which contain high levels of miR-130b-3p and promote survival, migration, invasion and angiogenesis in GC cells through the modulation of MLL3 (mixed-lineage leukemia protein 3) and GRHL2 (grainyhead-like protein 2 homolog) [99]. MiR-501-3p has been found to be highly expressed in pancreatic ductal adenocarcinoma (PDAC) tissues and TAM-derived exosomes. Exosomal miR-501-3p promotes cancer cell migration and invasion, as well as tumour formation and metastasis in vivo through regulation of TGFBR3 (transforming growth factor beta receptor 3) [100]. Finally, a study detected miR-223-3p in exosomes released by IL-4 (interleukin-4)-activated macrophages; this miRNA has been shown to transfer to breast tumour cells where it regulates invasion through the Mef2c (myocyte enhancer factor 2C)- $\beta$-catenin pathway [101]. 


\section{Conclusions and Perspectives}

The present review summarizes the role of miRNAs in metastasis with a focus on their role in the communication between tumour cells and TME cells. Deregulated miRNAs have been observed in both tumour and TME cells, highlighting the crucial role of miRNAs and tumour microenvironment in cancer progression and metastasis. Many of these miRNAs are secreted through EVs, mostly contained inside exosomes, and target many important cancer-related genes in recipient cells, many of which are related with the metastatic process (Table 1).

Table 1. List of miRNAs associated with metastasis and TME.

\begin{tabular}{|c|c|c|c|c|c|}
\hline miRNA & Cancer & Donor Cells & Receptor Cells & Target & Ref. \\
\hline miR-9 & Breast & Tumour cells & Fibroblasts & E-cadherin & [71] \\
\hline miR-10b-5p & $\mathrm{HCC}$ & Tumour cells & Tumour cells & - & [52] \\
\hline miR-15b-5p & GBM & Tumour cells & Non-tumour brain cells & MAPK/ERK & [51] \\
\hline miR-17-5p & CRC & CAFs & Tumour cells & RUNX3 & [74] \\
\hline $\operatorname{miR}-19 b-3 p$ & ccRCC & CSCs & Tumour cells & PTEN & [59] \\
\hline miR-20a-5p & Breast & Tumour cells & BMMs & SRCIN1 & [62] \\
\hline \multirow{2}{*}{ miR-21 } & Lung & Tumour cells & Pre-osteoclasts & PTEN & [65] \\
\hline & Lung & Tumour cells & Macrophages & TLR8 & [90] \\
\hline \multirow{6}{*}{ miR-21-5p } & GBM & Tumour cells & Non-tumour brain cells & MAPK/ERK & [51] \\
\hline & $\mathrm{HCC}$ & Tumour cells & Tumour cells & - & [52] \\
\hline & Breast & Tumour cells & Osteoclasts & PDCD4 & [64] \\
\hline & Breast & CAFs & Tumour cells & - & [73] \\
\hline & Bladder & Tumour cells & Macrophages & PTEN & [91] \\
\hline & Colon & TAMs & Tumour cells & BRG1 & [98] \\
\hline miR-25-3p & CRC & Tumour cells & Endothelial cells & KLF2/KLF4 & [82] \\
\hline miR-29a & Lung & Tumour cells & Macrophages & TLR8 & [90] \\
\hline $\operatorname{miR}-30 c-5 p$ & GBM & Tumour cells & Non-tumour brain cells & MAPK/ERK & [51] \\
\hline miR-30d-5p & GBM & Tumour cells & Non-tumour brain cells & MAPK/ERK & [51] \\
\hline $\operatorname{miR}-103 a-3 p$ & $\mathrm{HCC}$ & Tumour cells & Endothelial cells & VE-Cadherin & [81] \\
\hline miR-105 & Breast & Tumour cells & Endothelial cells & $\mathrm{ZO}-1$ & [83] \\
\hline miR-122 & Breast & Tumour cells & Fibroblasts/astrocytes & PKM2/GLUT1 & [67] \\
\hline miR-130b-3p & Gastric & TAMs & Tumour cells & MLL3/GRHL2 & [99] \\
\hline $\operatorname{miR}-143-3 p$ & Breast & CAFs & Tumour cells & - & [73] \\
\hline miR-155-5p & Colon & TAMs & Tumour cells & BRG1 & [98] \\
\hline \multirow{2}{*}{$\operatorname{miR}-210$} & Breast & Tumour cells & Endothelial cells & Ephrin A3 & [84] \\
\hline & Breast & Tumour cells & Endothelial cells & Ephrin A3/PTP1B & [85] \\
\hline $\operatorname{miR}-210-3 p$ & HCC & Tumour cells & Endothelial cells & SMAD4/STAT6 & [86] \\
\hline miR-211 & Melanoma & Tumour cells & Fibroblasts & IGF2R & [72] \\
\hline miR-214 & Lung & Tumour cells & Treg & PTEN & [94] \\
\hline $\operatorname{miR}-218-5 p$ & Breast & Tumour cells & Pre-osteoblasts & Col1a1 & [63] \\
\hline $\operatorname{miR}-223-3 p$ & Breast & TAMs & Tumour cells & Mef2c & [101] \\
\hline $\operatorname{miR}-301 a-3 p$ & Pancreatic & Tumour cells & Macrophages & PTEN & [93] \\
\hline $\operatorname{miR}-342-3 p$ & OSCC & High-metastatic cells & Low-metastatic cells & - & [60] \\
\hline miR-378e & Breast & CAFs & Tumour cells & - & [73] \\
\hline miR-501-3p & PDAC & TAMs & Tumour cells & TGDBR3 & [100] \\
\hline miR-934 & CRC & Tumour cells & Macrophages & PTEN & [92] \\
\hline miR-939-5p & Breast & Tumour cells & Endothelial cells & VE-cadherin & [80] \\
\hline $\operatorname{miR}-940$ & Prostate & Tumour cells & MSCs & $\begin{array}{l}\text { ARHGAP1 } \\
\text { FAM134A }\end{array}$ & [66] \\
\hline miR-1246 & OSCC & High-metastatic cells & Low-metastatic cells & DENND2D & [60] \\
\hline miR-1247-3p & HCC & High-metastatic cells & Fibroblasts & B4GALT3 & [70] \\
\hline
\end{tabular}

ccRCC, clear cell renal cell carcinoma; OSCC, oral squamous cell carcinoma; GBM, glioblastoma multiforme; HCC, hepatocellular carcinoma; CRC, colorectal cancer; PDAC, pancreatic ductal adenocarcinoma; CSC, cancer stem cells; BMM, bone marrow macrophages; MSCs, mesenchymal stem cells; CAF, cancer-associated fibroblasts; TAM, tumour-associated macrophages; Ref, reference.

MicroRNAs regulate expression of several genes related with metastasis, but at the same time miRNAs could be regulated by competing endogenous RNAs (ceRNAs). Competing endogenous RNAs contain sequences recognized by miRNAs and act as sponges 
of them, thus modulating gene expression. Competing endogenous RNAs include long non-coding RNAs (lncRNAs) and circular RNAs (circRNAs) [102]. In nasopharyngeal carcinoma, it has been described that overexpression of lncRNA FAM225A which regulates miR-590-3p and miR-1275 [103] and circRNA CRIM1 which regulates miR-422a [104] promote invasion and metastasis, respectively. Gastric cancer patients showed two differentially expressed circRNAs and both act as ceRNAs $[105,106]$. One of them, circNRIP1, was upregulated and was demonstrated to target the miR-149-5p/AKT1-mTOR axis promoting migration and invasion [105]. In contrast, circCCDC9 was downregulated and was shown to regulate migration and invasion through sponging of the miR-6792-3p/CAV1 axis [106]. Additionally the lncRNA linc00968 was found to be downregulated in lung adenocarcinoma acting as a sponge for miR-9-5p and miR-21-5p, thereby promoting metastasis through regulation of CPEB3 and SMAD7, respectively [107,108].

The discovery of metastasis-related miRNAs secreted by tumour cells or stromal cells in the TME allows us to use them as prognostic biomarkers in different types of cancer. In breast cancer, a 4-miRNA signature in tissue that could predict high or low risk of lymph node metastasis with an area under the curve (AUC) of 0.841 has been described, with poorer overall survival and disease-free survival in the high-risk group [109]. Another example is in prostate cancer, where tissue expression of miR-346 correlated with the Gleason grade, biochemical relapse and higher recurrence risk [110]. Moreover, metastasisrelated miRNAs were also found and detected in bodily fluids, such as serum, plasma and urine, among others, which allows the development of non-invasive metastasis biomarkers facilitating patient management [2]. Serum levels of miR-103a-3p and miR-1247-3p in HCC correlated with higher metastatic potential and lung metastasis, respectively $[70,81]$. Another example of non-invasive biomarkers is serum exosomal miR-301a-3p levels in pancreatic cancer, which correlated with tumour invasion, lymph node metastasis and poorer overall survival of patients [93]. These are just some examples of studies where the role of metastasis-related miRNAs as prognostic cancer biomarkers has been seen, but the field of study of miRNAs as biomarkers has grown in recent years. However, current studies evaluate their biomarker potential using different conservation, extraction and detection protocols, leading to inconsistent results that make difficult their application to clinical practice [111].

On the other hand, deregulated miRNAs in metastasis could be used as a therapeutic approach. There are two main strategies to modulate miRNAs, restoration of downregulated tumour suppressor miRNA (mimics) or inhibition of overexpressed onco-miRNA (antagomiRs) [112,113]. However, efficient delivery of miRNAs / miRNA inhibitors to target tissues is a major challenge in the transition of miRNA therapy to the clinical practice. Several companies are working on miRNA-based therapies and some of them have entered clinical trials, but only a small proportion of them are directed against cancer (Table 2) [114], so more efforts are needed to bring miRNA therapies from the bench to the clinic. The two main delivery approaches used in miRNA modulation are viral- and non-viral-based systems. Viral vectors, such as lentivirus, adenovirus or adeno-associated viruses are efficient delivery methods, but their systemic toxicity and immunogenicity limit their clinical use $[115,116]$. For this reason, several researchers focused on non-viral delivery systems, such as nanoparticles or exosomes, to deliver miRNAs / miRNA inhibitors; however, these approaches still present a lower efficiency than viral systems $[117,118]$. 
Table 2. Clinical trials of miRNA-based therapeutics to treat cancer.

\begin{tabular}{|c|c|c|c|c|c|c|c|}
\hline miRNA & Cancer & Product & Type & Phase & Company & $\begin{array}{c}\text { Clinical Trial } \\
\text { ID }\end{array}$ & Ref. \\
\hline $\mathrm{miR}-10 \mathrm{~b}$ & GBM & RGLS5579 & AntagomiR & Not iniciated & $\begin{array}{c}\text { Regulus } \\
\text { Therapeutics }\end{array}$ & - & - \\
\hline miR-16 & $\begin{array}{l}\text { Mesothelioma and } \\
\text { NSCLC }\end{array}$ & MesomiR-1 & TargomiR & Phase 2 & ENGeneIC & NCT02369198 & [119] \\
\hline $\operatorname{miR}-34$ & $\begin{array}{l}\text { Liver, lymphoma, } \\
\text { melanoma, SCLC, } \\
\text { MM, RCC, NSCLC }\end{array}$ & MRX34 & Mimic & Withdrawn & $\begin{array}{c}\text { Mirna } \\
\text { Therapeutics }\end{array}$ & $\begin{array}{l}\text { NCT01829971 } \\
\text { NCT02862145 }\end{array}$ & [120] \\
\hline miR-155 & T cell lymphoma & MRG-106 & AntagomiR & Phase 2 & $\begin{array}{c}\text { MiRagen } \\
\text { Therapeutics }\end{array}$ & NCT03713320 & [121] \\
\hline
\end{tabular}

GBM, glioblastoma multiforme; NSCLC, non-small-cell lung cancer; SCLC, small-cell lung cancer; MM, multiple myeloma; RCC, renal cell carcinoma; Ref, reference.

As mentioned above, EVs secreted by tumour cells play an important role in promoting metastasis, so it would be tempting to infer that inhibiting EV biogenesis and secretion could be another promising strategy for cancer therapy. It has been shown that sulfisoxazole, an FDA-approved antibiotic, inhibits secretion of small EVs from breast cancer through interference with ETA (endothelin receptor A) and inhibits cancer progression and metastasis as demonstrated in mouse models [122]. Another study screened more than 4000 compounds to target exosomes from cancer cells. These authors found that manumycin A, a natural microbial metabolite, could inhibit exosome biogenesis and secretion in castration-resistant prostate cancer through inhibition of the Ras/Raf/ERK signalling pathway [123]. In addition to targeting EV biogenesis and secretion, EVs could be prevented from reaching their target cells. For example, it has been reported that treatment with EV-specific anti-CD9 or anti-CD63 significantly decreased breast cancer metastasis to the lungs, lymph nodes and thoracic cavity [124]. Ortiz et al. demonstrated that melanoma EVs could downregulate IFNAR1 (type I interferon receptor) and $\mathrm{CH} 25 \mathrm{H}$ (cholesterol 25-hydroxylase) in normal cells to facilitate EV uptake and premetastatic niche formation. Upregulation of IFNAR1- $\mathrm{CH} 25 \mathrm{H}$ or treatment with reserpine, an antihypertensive drug, limited melanoma EV uptake by normal cells and inhibited tumour progression and reduced lung metastasis [125].

In summary, metastasis-related miRNA plays an important role in cell-to-cell communication, which helps tumour cells to survive, grow and spread to other organs. Its presence in tumour tissue and body fluids gives us the opportunity to use them to our benefit, either as prognostic biomarkers to improve patient management or by developing new therapies to reverse the effect of these miRNAs. Nevertheless, for these applications, it is necessary to develop and establish standardized approaches, conduct more multicentre studies and improve approaches to EV disruption and miRNA-based therapies.

Author Contributions: C.S. and C.H.L. conceived, drafted, edited and wrote the final manuscript. All authors have read and agreed to the published version of the manuscript.

Funding: This research received no external funding.

Institutional Review Board Statement: No applicable.

Informed Consent Statement: Not applicable.

Data Availability Statement: Not applicable.

Acknowledgments: C.H.L. and his research are supported by grants from the IKERBASQUE Foundation for Science, the Starmer-Smith Memorial Fund, Ministerio de Economía y Competitividad (MINECO) of the Spanish Central Government, the ISCIII and FEDER funds (PI12/00663, PIE13/00048, DTS14/00109, PI15/00275, PI18/01710), Departamento de Desarrollo Económico y Competitividad y Departamento de Sanidad of the Basque government, Asociación Española Contra el Cancer (AECC), Diputación Foral de Guipuzcoa (DFG) and Gobierno Vasco, Departamento de Industria (ELKARTEK project code: KK-2018/00038). 
Conflicts of Interest: The authors declare no conflict of interest.

\section{References}

1. Robert, J. Biology of cancer metastasis. Bull. Du Cancer 2013, 100, 333-342. [CrossRef]

2. Sole, C.; Arnaiz, E.; Manterola, L.; Otaegui, D.; Lawrie, C.H. The circulating transcriptome as a source of cancer liquid biopsy biomarkers. Semin. Cancer Biol. 2019, 58, 100-108. [CrossRef] [PubMed]

3. Hanahan, D.; Weinberg, R.A. The hallmarks of cancer. Cell 2000, 100, 57-70. [CrossRef]

4. Seyfried, T.N.; Huysentruyt, L.C. On the origin of cancer metastasis. Crit. Rev. Oncog. 2013, 18, 43-73. [CrossRef] [PubMed]

5. Chambers, A.F.; Groom, A.C.; MacDonald, I.C. Dissemination and growth of cancer cells in metastatic sites. Nat. Rev. Cancer 2002, 2, 563-572. [CrossRef]

6. Naito, Y.; Yoshioka, Y.; Yamamoto, Y.; Ochiya, T. How cancer cells dictate their microenvironment: Present roles of extracellular vesicles. Cell. Mol. Life Sci. Cmls 2017, 74, 697-713. [CrossRef] [PubMed]

7. Fidler, I.J. The pathogenesis of cancer metastasis: The 'seed and soil' hypothesis revisited. Nat. Rev. Cancer 2003, 3, 453-458. [CrossRef]

8. Quail, D.F.; Joyce, J.A. Microenvironmental regulation of tumor progression and metastasis. Nat. Med. 2013, $19,1423-1437$. [CrossRef]

9. Giraldo, N.A.; Sanchez-Salas, R.; Peske, J.D.; Vano, Y.; Becht, E.; Petitprez, F.; Validire, P.; Ingels, A.; Cathelineau, X.; Fridman, W.H.; et al. The clinical role of the TME in solid cancer. Br. J. Cancer 2019, 120, 45-53. [CrossRef]

10. Hanahan, D.; Coussens, L.M. Accessories to the crime: Functions of cells recruited to the tumor microenvironment. Cancer Cell 2012, 21, 309-322. [CrossRef] [PubMed]

11. Rossi, G.R.; Trindade, E.S.; Souza-Fonseca-Guimaraes, F. Tumor Microenvironment-Associated Extracellular Matrix Components Regulate NK Cell Function. Front. Immunol. 2020, 11, 73. [CrossRef]

12. Ackerman, D.; Simon, M.C. Hypoxia, lipids, and cancer: Surviving the harsh tumor microenvironment. Trends Cell Biol. 2014, 24, 472-478. [CrossRef] [PubMed]

13. Huang, Y.; Lin, D.; Taniguchi, C.M. Hypoxia inducible factor (HIF) in the tumor microenvironment: Friend or foe? Sci. China Life Sci. 2017, 60, 1114-1124. [CrossRef] [PubMed]

14. Lu, X.; Kang, Y. Hypoxia and hypoxia-inducible factors: Master regulators of metastasis. Clin. Cancer Res. Off. J. Am. Assoc. Cancer Res. 2010, 16, 5928-5935. [CrossRef] [PubMed]

15. Moriwaki, K.; Asahi, M. Augmented TME O-GlcNAcylation Promotes Tumor Proliferation through the Inhibition of p38 MAPK. Mol. Cancer Res. MCR 2017, 15, 1287-1298. [CrossRef]

16. Lei, X.; Lei, Y.; Li, J.K.; Du, W.X.; Li, R.G.; Yang, J.; Li, J.; Li, F.; Tan, H.B. Immune cells within the tumor microenvironment: Biological functions and roles in cancer immunotherapy. Cancer Lett. 2020, 470, 126-133. [CrossRef]

17. De Palma, M.; Biziato, D.; Petrova, T.V. Microenvironmental regulation of tumour angiogenesis. Nat. Reviews. Cancer 2017, 17, 457-474. [CrossRef] [PubMed]

18. Soon, P.; Kiaris, H. MicroRNAs in the tumour microenvironment: Big role for small players. Endocr. Relat. Cancer 2013, 20, R257-R267. [CrossRef] [PubMed]

19. Chou, J.; Shahi, P.; Werb, Z. microRNA-mediated regulation of the tumor microenvironment. Cell Cycle (Georget. Tex.) 2013, 12, 3262-3271. [CrossRef] [PubMed]

20. Lee, R.C.; Feinbaum, R.L.; Ambros, V. The C. elegans heterochronic gene lin-4 encodes small RNAs with antisense complementarity to lin-14. Cell 1993, 75, 843-854. [CrossRef]

21. Bartel, D.P. MicroRNAs: Genomics, biogenesis, mechanism, and function. Cell 2004, 116, 281-297. [CrossRef]

22. Bartel, D.P. MicroRNAs: Target recognition and regulatory functions. Cell 2009, 136, 215-233. [CrossRef]

23. Berindan-Neagoe, I.; Monroig Pdel, C.; Pasculli, B.; Calin, G.A. MicroRNAome genome: A treasure for cancer diagnosis and therapy. CA A Cancer J. Clin. 2014, 64, 311-336. [CrossRef] [PubMed]

24. Friedman, R.C.; Farh, K.K.; Burge, C.B.; Bartel, D.P. Most mammalian mRNAs are conserved targets of microRNAs. Genome Res. 2009, 19, 92-105. [CrossRef]

25. Gambari, R.; Brognara, E.; Spandidos, D.A.; Fabbri, E. Targeting oncomiRNAs and mimicking tumor suppressor miRNAs: New trends in the development of miRNA therapeutic strategies in oncology (Review). Int. J. Oncol. 2016, 49, 5-32. [CrossRef] [PubMed]

26. Ma, L.; Teruya-Feldstein, J.; Weinberg, R.A. Tumour invasion and metastasis initiated by microRNA-10b in breast cancer. Nature 2007, 449, 682-688. [CrossRef] [PubMed]

27. Yu, F.; Yao, H.; Zhu, P.; Zhang, X.; Pan, Q.; Gong, C.; Huang, Y.; Hu, X.; Su, F.; Lieberman, J.; et al. let-7 regulates self renewal and tumorigenicity of breast cancer cells. Cell 2007, 131, 1109-1123. [CrossRef]

28. Solé, C.; Lawrie, C.H. MicroRNAs and Metastasis. Cancers 2019, 12, 96. [CrossRef] [PubMed]

29. de Rie, D.; Abugessaisa, I. An integrated expression atlas of miRNAs and their promoters in human and mouse. Nat. Biotechnol. 2017, 35, 872-878. [CrossRef] [PubMed]

30. Forrest, A.R.R.; de Hoon, M.J.L.; Ha, M.; Kim, V.N. Regulation of microRNA biogenesis. Nat. Biotechnol. 2014, 15, 509-524.

31. Denli, A.M.; Tops, B.B.; Plasterk, R.H.; Ketting, R.F.; Hannon, G.J. Processing of primary microRNAs by the Microprocessor complex. Nature 2004, 432, 231-235. [CrossRef] [PubMed] 
32. Alarcón, C.R.; Lee, H.; Goodarzi, H.; Halberg, N.; Tavazoie, S.F. N6-methyladenosine marks primary microRNAs for processing. Nature 2015, 519, 482-485. [CrossRef] [PubMed]

33. Okada, C.; Yamashita, E.; Lee, S.J.; Shibata, S.; Katahira, J.; Nakagawa, A.; Yoneda, Y.; Tsukihara, T. A high-resolution structure of the pre-microRNA nuclear export machinery. Science 2009, 326, 1275-1279. [CrossRef]

34. Zhang, H.; Kolb, F.A.; Jaskiewicz, L.; Westhof, E.; Filipowicz, W. Single processing center models for human Dicer and bacterial RNase III. Cell 2004, 118, 57-68. [CrossRef] [PubMed]

35. Yoda, M.; Kawamata, T.; Paroo, Z.; Ye, X.; Iwasaki, S.; Liu, Q.; Tomari, Y. ATP-dependent human RISC assembly pathways. Nat. Struct. Mol. Biol. 2010, 17, 17-23. [CrossRef]

36. Kawamata, T.; Tomari, Y. Making RISC. Trends Biochem. Sci. 2010, 35, 368-376. [CrossRef]

37. Huntzinger, E.; Izaurralde, E. Gene silencing by microRNAs: Contributions of translational repression and mRNA decay. Nat. Rev. Genet. 2011, 12, 99-110. [CrossRef] [PubMed]

38. Jackson, R.J.; Standart, N. How do microRNAs regulate gene expression? Sci. Stke Signal Transduct. Knowl. Environ. 2007, 2007, re1. [CrossRef]

39. Forman, J.J.; Legesse-Miller, A.; Coller, H.A. A search for conserved sequences in coding regions reveals that the let-7 microRNA targets Dicer within its coding sequence. Proc. Natl. Acad. Sci. USA 2008, 105, 14879-14884. [CrossRef]

40. Stavast, C.J.; Erkeland, S.J. The Non-Canonical Aspects of MicroRNAs: Many Roads to Gene Regulation. Cells 2019, 8, 1465. [CrossRef] [PubMed]

41. Raposo, G.; Stoorvogel, W. Extracellular vesicles: Exosomes, microvesicles, and friends. J. Cell Biol. 2013, 200, 373-383. [CrossRef]

42. Arroyo, J.D.; Chevillet, J.R.; Kroh, E.M.; Ruf, I.K.; Pritchard, C.C.; Gibson, D.F.; Mitchell, P.S.; Bennett, C.F.; Pogosova-Agadjanyan, E.L.; Stirewalt, D.L.; et al. Argonaute2 complexes carry a population of circulating microRNAs independent of vesicles in human plasma. Proc. Natl. Acad. Sci. USA 2011, 108, 5003-5008. [CrossRef] [PubMed]

43. Vickers, K.C.; Remaley, A.T. Lipid-based carriers of microRNAs and intercellular communication. Curr. Opin. Lipidol. 2012, 23, 91-97. [CrossRef]

44. Valadi, H.; Ekström, K.; Bossios, A.; Sjöstrand, M.; Lee, J.J.; Lötvall, J.O. Exosome-mediated transfer of mRNAs and microRNAs is a novel mechanism of genetic exchange between cells. Nat. Cell Biol. 2007, 9, 654-659. [CrossRef]

45. Cui, M.; Wang, H.; Yao, X.; Zhang, D.; Xie, Y.; Cui, R.; Zhang, X. Circulating MicroRNAs in Cancer: Potential and Challenge. Front. Genet. 2019, 10, 626. [CrossRef] [PubMed]

46. Becker, A.; Thakur, B.K.; Weiss, J.M.; Kim, H.S.; Peinado, H.; Lyden, D. Extracellular Vesicles in Cancer: Cell-to-Cell Mediators of Metastasis. Cancer Cell 2016, 30, 836-848. [CrossRef]

47. Peinado, H.; Zhang, H.; Matei, I.R.; Costa-Silva, B.; Hoshino, A.; Rodrigues, G.; Psaila, B.; Kaplan, R.N.; Bromberg, J.F.; Kang, Y.; et al. Pre-metastatic niches: Organ-specific homes for metastases. Nat. Rev. Cancer 2017, 17, 302-317. [CrossRef]

48. Guo, Y.; Ji, X.; Liu, J.; Fan, D.; Zhou, Q.; Chen, C.; Wang, W.; Wang, G.; Wang, H.; Yuan, W.; et al. Effects of exosomes on pre-metastatic niche formation in tumors. Mol. Cancer 2019, 18, 124. [CrossRef] [PubMed]

49. Mulcahy, L.A.; Pink, R.C.; Carter, D.R. Routes and mechanisms of extracellular vesicle uptake. J. Extracell. Vesicles 2014, 3. [CrossRef] [PubMed]

50. Gangoda, L.; Boukouris, S.; Liem, M.; Kalra, H.; Mathivanan, S. Extracellular vesicles including exosomes are mediators of signal transduction: Are they protective or pathogenic? Proteomics 2015, 15, 260-271. [CrossRef]

51. Bertolini, I.; Storaci, A.M. Interplay Between V-ATPase G1 and Small EV-miRNAs Modulates ERK1/2 Activation in GBM Stem Cells and Nonneoplastic Milieu. Tumor Microenviron. Immunobiol. 2020, 18, 1744-1754. [CrossRef]

52. Tian, X.P.; Wang, C.Y.; Jin, X.H.; Li, M.; Wang, F.W.; Huang, W.J.; Yun, J.P.; Xu, R.H.; Cai, Q.Q.; Xie, D. Acidic Microenvironment Up-Regulates Exosomal miR-21 and miR-10b in Early-Stage Hepatocellular Carcinoma to Promote Cancer Cell Proliferation and Metastasis. Mol. Cancer Res. MCR 2019, 9, 1965-1979. [CrossRef] [PubMed]

53. Koren, E.; Fuchs, Y. The bad seed: Cancer stem cells in tumor development and resistance. Drug Resist. Updat. Rev. Comment. Antimicrob. Anticancer Chemother. 2016, 28, 1-12. [CrossRef] [PubMed]

54. Dimou, A.; Syrigos, K.N.; Saif, M.W. Overcoming the stromal barrier: Technologies to optimize drug delivery in pancreatic cancer. Ther. Adv. Med Oncol. 2012, 4, 271-279. [CrossRef] [PubMed]

55. Lawson, D.A.; Bhakta, N.R.; Kessenbrock, K.; Prummel, K.D.; Yu, Y.; Takai, K.; Zhou, A.; Eyob, H.; Balakrishnan, S.; Wang, C.Y.; et al. Single-cell analysis reveals a stem-cell program in human metastatic breast cancer cells. Nature 2015, 526, 131-135. [CrossRef]

56. Charafe-Jauffret, E.; Ginestier, C.; Iovino, F.; Wicinski, J.; Cervera, N.; Finetti, P.; Hur, M.H.; Diebel, M.E.; Monville, F.; Dutcher, J.; et al. Breast cancer cell lines contain functional cancer stem cells with metastatic capacity and a distinct molecular signature. Cancer Res. 2009, 69, 1302-1313. [CrossRef] [PubMed]

57. Pang, R.; Law, W.L.; Chu, A.C.; Poon, J.T.; Lam, C.S.; Chow, A.K.; Ng, L.; Cheung, L.W.; Lan, X.R.; Lan, H.Y.; et al. A subpopulation of CD26+ cancer stem cells with metastatic capacity in human colorectal cancer. Cell Stem Cell 2010, 6, 603-615. [CrossRef]

58. Marcato, P.; Dean, C.A.; Pan, D.; Araslanova, R.; Gillis, M.; Joshi, M.; Helyer, L.; Pan, L.; Leidal, A.; Gujar, S.; et al. Aldehyde dehydrogenase activity of breast cancer stem cells is primarily due to isoform ALDH1A3 and its expression is predictive of metastasis. Stem Cells 2011, 29, 32-45. [CrossRef]

59. Wang, L.; Yang, G.; Zhao, D.; Wang, J.; Bai, Y.; Peng, Q.; Wang, H.; Fang, R.; Chen, G.; Wang, Z.; et al. CD103-positive CSC exosome promotes EMT of clear cell renal cell carcinoma: Role of remote MiR-19b-3p. Mol. Cancer 2019, 18, 86. [CrossRef] 
60. Sakha, S.; Muramatsu, T.; Ueda, K.; Inazawa, J. Exosomal microRNA miR-1246 induces cell motility and invasion through the regulation of DENND2D in oral squamous cell carcinoma. Sci. Rep. 2016, 6, 38750. [CrossRef]

61. Kingsley, L.A.; Fournier, P.G.; Chirgwin, J.M.; Guise, T.A. Molecular biology of bone metastasis. Mol. Cancer Ther. 2007, 6, 2609-2617. [CrossRef] [PubMed]

62. Guo, L.; Zhu, Y.; Li, L.; Zhou, S.; Yin, G.; Yu, G.; Cui, H. Breast cancer cell-derived exosomal miR-20a-5p promotes the proliferation and differentiation of osteoclasts by targeting SRCIN1. Cancer Med. 2019, 8, 5687-5701. [CrossRef]

63. Liu, X.; Cao, M.; Palomares, M.; Wu, X.; Li, A.; Yan, W.; Fong, M.Y.; Chan, W.C.; Wang, S.E. Metastatic breast cancer cells overexpress and secrete miR-218 to regulate type I collagen deposition by osteoblasts. Cancer Med. 2018, 20, 127. [CrossRef]

64. Yuan, X.; Qian, N.; Ling, S.; Li, Y.; Sun, W.; Li, J.; Du, R.; Zhong, G.; Liu, C.; Yu, G.; et al. Breast cancer exosomes contribute to pre-metastatic niche formation and promote bone metastasis of tumor cells. Breast Cancer Res. BCR 2021, 11, 1429-1445.

65. Zhao, Q.; Liu, C.; Xie, Y.; Tang, M.; Luo, G.; Chen, X.; Tian, L.; Yu, X. Lung Cancer Cells Derived Circulating miR-21 Promotes Differentiation of Monocytes into Osteoclasts. OncoTargets Ther. 2020, 13, 2643-2656. [CrossRef] [PubMed]

66. Hashimoto, K.; Ochi, H.; Sunamura, S.; Kosaka, N.; Mabuchi, Y. Cancer-secreted hsa-miR-940 induces an osteoblastic phenotype in the bone metastatic microenvironment via targeting ARHGAP1 and FAM134A. Oncotargets Ther. 2018, 115, 2204-2209. [CrossRef]

67. Fukuda, T.; Yao, K.; Kanda, H.; Ae, K.; Okawa, A.; Akazawa, C.; Ochiya, T.; Futakuchi, M.; Takeda, S.; Sato, S.; et al. Breast-cancersecreted miR-122 reprograms glucose metabolism in premetastatic niche to promote metastasis. Proc. Natl. Acad. Sci. USA 2015, 17, 183-194.

68. Ping, Q.; Yan, R.; Cheng, X.; Wang, W.; Zhong, Y.; Hou, Z.; Shi, Y.; Wang, C. Cancer-associated fibroblasts: Overview, progress, challenges, and directions. Cancer. Gene. Ther. 2021. [CrossRef]

69. Shoucair, I.; Weber Mello, F. The Role of Cancer-Associated Fibroblasts and Extracellular Vesicles in Tumorigenesis. Cancer Gene Ther. 2020, 21, 6837. [CrossRef]

70. Fang, T.; Lv, H.; Lv, G.; Li, T.; Wang, C.; Han, Q.; Yu, L.; Su, B.; Guo, L.; Huang, S.; et al. Tumor-derived exosomal miR-1247-3p induces cancer-associated fibroblast activation to foster lung metastasis of liver cancer. Nat. Commun. 2018, 9, 191. [CrossRef]

71. Baroni, S.; Romero-Cordoba, S.; Plantamura, I.; Dugo, M.; D’Ippolito, E.; Cataldo, A.; Cosentino, G.; Angeloni, V.; Rossini, A.; Daidone, M.G.; et al. Exosome-mediated delivery of miR-9 induces cancer-associated fibroblast-like properties in human breast fibroblasts. Cell Death Dis. 2016, 7, e2312. [CrossRef] [PubMed]

72. Dror, S.; Sander, L.; Schwartz, H.; Sheinboim, D.; Barzilai, A.; Dishon, Y.; Apcher, S.; Golan, T.; Greenberger, S.; Barshack, I.; et al. Melanoma miRNA trafficking controls tumour primary niche formation. Nat. Cell Biol. 2016, 18, 1006-1017. [CrossRef]

73. Donnarumma, E.; Fiore, D.; Nappa, M.; Roscigno, G.; Adamo, A.; Iaboni, M.; Russo, V.; Affinito, A.; Puoti, I.; Quintavalle, C.; et al. Cancer-associated fibroblasts release exosomal microRNAs that dictate an aggressive phenotype in breast cancer. Oncotarget 2017, 8, 19592-19608. [CrossRef] [PubMed]

74. Zhang, Y.; Wang, S.; Lai, Q.; Fang, Y.; Wu, C.; Liu, Y.; Li, Q.; Wang, X.; Gu, C.; Chen, J.; et al. Cancer-associated fibroblasts-derived exosomal miR-17-5p promotes colorectal cancer aggressive phenotype by initiating a RUNX3/MYC/TGF- $\beta 1$ positive feedback loop. Cancer Lett. 2020, 491, 22-35. [CrossRef] [PubMed]

75. Mitra, A.K.; Zillhardt, M.; Hua, Y.; Tiwari, P.; Murmann, A.E.; Peter, M.E.; Lengyel, E. MicroRNAs reprogram normal fibroblasts into cancer-associated fibroblasts in ovarian cancer. Cancer Discov. 2012, 2, 1100-1108. [CrossRef] [PubMed]

76. Tang, X.; Hou, Y.; Yang, G.; Wang, X.; Tang, S.; Du, Y.E.; Yang, L.; Yu, T.; Zhang, H.; Zhou, M.; et al. Stromal miR-200s contribute to breast cancer cell invasion through CAF activation and ECM remodeling. Cell Death Differ. 2016, 23, 132-145. [CrossRef] [PubMed]

77. Du, Y.E.; Tu, G.; Yang, G.; Li, G.; Yang, D.; Lang, L.; Xi, L.; Sun, K.; Chen, Y.; Shu, K.; et al. MiR-205/YAP1 in Activated Fibroblasts of Breast Tumor Promotes VEGF-independent Angiogenesis through STAT3 Signaling. Theranostics 2017, 7, 3972-3988. [CrossRef] [PubMed]

78. Martin, T.A. The role of tight junctions in cancer metastasis. Semin. Cell Dev. Biol. 2014, 36, 224-231. [CrossRef]

79. Potente, M.; Gerhardt, H.; Carmeliet, P. Basic and therapeutic aspects of angiogenesis. Cell 2011, 146, 873-887. [CrossRef]

80. Di Modica, M.; Regondi, V.; Sandri, M.; Iorio, M.V.; Zanetti, A.; Tagliabue, E.; Casalini, P.; Triulzi, T. Breast cancer-secreted miR-939 downregulates VE-cadherin and destroys the barrier function of endothelial monolayers. Cancer Lett. 2017, 384, 94-100. [CrossRef] [PubMed]

81. Fang, J.H.; Zhang, Z.J.; Shang, L.R.; Luo, Y.W.; Lin, Y.F.; Yuan, Y.; Zhuang, S.M. Hepatoma cell-secreted exosomal microRNA-103 increases vascular permeability and promotes metastasis by targeting junction proteins. Hepatology 2018, 68, 1459-1475. [CrossRef] [PubMed]

82. Zeng, Z.; Li, Y.; Pan, Y.; Lan, X.; Song, F.; Sun, J.; Zhou, K.; Liu, X.; Ren, X.; Wang, F.; et al. Cancer-derived exosomal miR-25-3p promotes pre-metastatic niche formation by inducing vascular permeability and angiogenesis. Nat. Commun. 2018, 9, 5395. [CrossRef] [PubMed]

83. Zhou, W.; Fong, M.Y.; Min, Y.; Somlo, G.; Liu, L.; Palomares, M.R.; Yu, Y.; Chow, A.; O'Connor, S.T.; Chin, A.R.; et al. Cancersecreted miR-105 destroys vascular endothelial barriers to promote metastasis. Cancer Cell 2014, 25, 501-515. [CrossRef]

84. Kosaka, N.; Iguchi, H.; Hagiwara, K.; Yoshioka, Y.; Takeshita, F.; Ochiya, T. Neutral sphingomyelinase 2 (nSMase2)-dependent exosomal transfer of angiogenic microRNAs regulate cancer cell metastasis. J. Biol. Chem. 2013, 288, 10849-10859. [CrossRef]

85. Jung, K.O.; Youn, H.; Lee, C.H.; Kang, K.W.; Chung, J.K. Visualization of exosome-mediated miR-210 transfer from hypoxic tumor cells. Oncotarget 2017, 8, 9899-9910. [CrossRef] 
86. Lin, X.J.; Fang, J.H.; Yang, X.J.; Zhang, C.; Yuan, Y.; Zheng, L.; Zhuang, S.M. Hepatocellular Carcinoma Cell-Secreted Exosomal MicroRNA-210 Promotes Angiogenesis In Vitro and In Vivo. Mol. Ther. Nucleic Acids 2018, 11, 243-252. [CrossRef]

87. Parisi, L.; Gini, E. Macrophage Polarization in Chronic Inflammatory Diseases: Killers or Builders? J. Immunol. Res. 2018, 2018, 8917804. [CrossRef] [PubMed]

88. Mortara, L.; Yunna, C.; Mengru, H.; Lei, W.; Weidong, C. Macrophage M1/M2 polarization. J. Immunol. Res. 2020, 877, 173090.

89. Shapouri-Moghaddam, A.; Mohammadian, S.; Vazini, H.; Taghadosi, M.; Esmaeili, S.A.; Mardani, F.; Seifi, B.; Mohammadi, A.; Afshari, J.T.; Sahebkar, A. Macrophage plasticity, polarization, and function in health and disease. J. Cell. Physiol. 2018, 233, 6425-6440. [CrossRef]

90. Fabbri, M.; Paone, A.; Calore, F.; Galli, R.; Gaudio, E.; Santhanam, R.; Lovat, F.; Fadda, P.; Mao, C.; Nuovo, G.J.; et al. MicroRNAs bind to Toll-like receptors to induce prometastatic inflammatory response. J. Cell. Physiol. 2012, 109, E2110-E2116. [CrossRef]

91. Lin, F.; Yin, H.B.; Li, X.Y.; Zhu, G.M.; He, W.Y.; Gou, X. Bladder cancer cell-secreted exosomal miR-21 activates the PI3K/AKT pathway in macrophages to promote cancer progression. Int. J. Oncol. 2020, 56, 151-164. [CrossRef] [PubMed]

92. Zhao, S.; Mi, Y.; Guan, B.; Zheng, B.; Wei, P.; Gu, Y.; Zhang, Z.; Cai, S.; Xu, Y.; Li, X.; et al. Tumor-derived exosomal miR-934 induces macrophage M2 polarization to promote liver metastasis of colorectal cancer. J. Hematol. Oncol. 2020, 13, 156. [CrossRef] [PubMed]

93. Wang, X.; Luo, G.; Zhang, K.; Cao, J.; Huang, C.; Jiang, T.; Liu, B.; Su, L.; Qiu, Z. Hypoxic Tumor-Derived Exosomal miR-301a Mediates M2 Macrophage Polarization via PTEN/PI3Kgamma to Promote Pancreatic Cancer Metastasis. Cancer Res. 2018, 78 , 4586-4598. [CrossRef]

94. Yin, Y.; Cai, X.; Chen, X.; Liang, H.; Zhang, Y.; Li, J.; Wang, Z.; Chen, X.; Zhang, W.; Yokoyama, S.; et al. Tumor-secreted miR-214 induces regulatory T cells: A major link between immune evasion and tumor growth. Cell Res. 2014, 24, 1164-1180. [CrossRef] [PubMed]

95. Sánchez-González, I.; Bobien, A.; Molnar, C.; Schmid, S.; Strotbek, M.; Boerries, M. miR-149 Suppresses Breast Cancer Metastasis by Blocking Paracrine Interactions with Macrophages. Cancer Res. 2020, 80, 1330-1341. [CrossRef]

96. Ke, M.; Zhang, Z.; Cong, L.; Zhao, S.; Li, Y.; Wang, X.; Lv, Y.; Zhu, Y.; Dong, J. MicroRNA-148b-colony-stimulating factor-1 signaling-induced tumor-associated macrophage infiltration promotes hepatocellular carcinoma metastasis. Cancer Res. 2019, 120, 109523. [CrossRef] [PubMed]

97. Chen, E.B.; Zhou, Z.J.; Xiao, K.; Zhu, G.Q.; Yang, Y.; Wang, B.; Zhou, S.L.; Chen, Q.; Yin, D.; Wang, Z.; et al. The miR-5615p/CX(3)CL1 Signaling Axis Regulates Pulmonary Metastasis in Hepatocellular Carcinoma Involving CX(3)CR1(+) Natural Killer Cells Infiltration. Theranostics 2019, 9, 4779-4794. [CrossRef]

98. Lan, J.; Sun, L.; Xu, F.; Liu, L.; Hu, F.; Song, D.; Hou, Z.; Wu, W.; Luo, X.; Wang, J.; et al. M2 Macrophage-Derived Exosomes Promote Cell Migration and Invasion in Colon Cancer. Cancer Res. 2019, 79, 146-158. [CrossRef]

99. Zhang, Y.; Meng, W.; Yue, P.; Li, X. M2 macrophage-derived extracellular vesicles promote gastric cancer progression via a microRNA-130b-3p/MLL3/GRHL2 signaling cascade. J. Exp. Clin. Cancer Res. CR 2020, 39, 134. [CrossRef]

100. Yin, Z.; Ma, T.; Huang, B.; Lin, L.; Zhou, Y.; Yan, J.; Zou, Y.; Chen, S. Macrophage-derived exosomal microRNA-501-3p promotes progression of pancreatic ductal adenocarcinoma through the TGFBR3-mediated TGF- $\beta$ signaling pathway. J. Exp. Clin. Cancer Res. CR 2019, 38, 310. [CrossRef]

101. Yang, M.; Chen, J.; Su, F.; Yu, B.; Su, F.; Lin, L.; Liu, Y.; Huang, J.D.; Song, E. Microvesicles secreted by macrophages shuttle invasion-potentiating microRNAs into breast cancer cells. Mol. Cancer 2011, 10, 117. [CrossRef] [PubMed]

102. Kartha, R.V.; Subramanian, S. Competing endogenous RNAs (ceRNAs): New entrants to the intricacies of gene regulation. Front. Genet. 2014, 5, 8. [CrossRef]

103. Zheng, Z.Q.; Li, Z.X.; Zhou, G.Q.; Lin, L.; Zhang, L.L.; Lv, J.W.; Huang, X.D.; Liu, R.Q.; Chen, F.; He, X.J.; et al. Long Noncoding RNA FAM225A Promotes Nasopharyngeal Carcinoma Tumorigenesis and Metastasis by Acting as ceRNA to Sponge miR-590-3p/miR-1275 and Upregulate ITGB3. Cancer Res. 2019, 79, 4612-4626. [CrossRef] [PubMed]

104. Hong, X.; Liu, N.; Liang, Y.; He, Q.; Yang, X.; Lei, Y.; Zhang, P.; Zhao, Y.; He, S.; Wang, Y.; et al. Circular RNA CRIM1 functions as a ceRNA to promote nasopharyngeal carcinoma metastasis and docetaxel chemoresistance through upregulating FOXQ1. Mol. Cancer 2020, 19, 33. [CrossRef] [PubMed]

105. Zhang, X.; Wang, S.; Wang, H.; Cao, J.; Huang, X.; Chen, Z.; Xu, P.; Sun, G.; Xu, J.; Lv, J.; et al. Circular RNA circNRIP1 acts as a microRNA-149-5p sponge to promote gastric cancer progression via the AKT1/mTOR pathway. Mol. Cancer 2019, 18, 20. [CrossRef]

106. Luo, Z.; Rong, Z.; Zhang, J.; Zhu, Z.; Yu, Z.; Li, T.; Fu, Z.; Qiu, Z.; Huang, C. Circular RNA circCCDC9 acts as a miR-6792-3p sponge to suppress the progression of gastric cancer through regulating CAV1 expression. Mol. Cancer 2020, 19, 86. [CrossRef]

107. Tang, H.; Han, X.; Feng, Y.; Hao, Y. linc00968 inhibits the tumorigenesis and metastasis of lung adenocarcinoma via serving as a ceRNA against miR-9-5p and increasing CPEB3. Aging 2020, 12, 22582-22598. [CrossRef]

108. Zhu, Y.; Bo, H.; Chen, Z.; Li, J.; He, D.; Xiao, M.; Xiang, L.; Jin, L.; Zhou, J.; Gong, L.; et al. LINC00968 can inhibit the progression of lung adenocarcinoma through the miR-21-5p/SMAD7 signal axis. Aging 2020, 12, 21904-21922. [CrossRef]

109. Chen, X.; Wang, Y.W.; Zhu, W.J.; Li, Y.; Liu, L.; Yin, G.; Gao, P. A 4-microRNA signature predicts lymph node metastasis and prognosis in breast cancer. Hum. Pathol. 2018, 76, 122-132. [CrossRef] 
110. Fletcher, C.E.; Sulpice, E.; Combe, S.; Shibakawa, A.; Leach, D.A.; Hamilton, M.P.; Chrysostomou, S.L.; Sharp, A.; Welti, J.; Yuan, W.; et al. Androgen receptor-modulatory microRNAs provide insight into therapy resistance and therapeutic targets in advanced prostate cancer. Oncogene 2019, 38, 5700-5724. [CrossRef]

111. Fernandez-Mercado, M.; Manterola, L.; Larrea, E.; Goicoechea, I.; Arestin, M.; Armesto, M.; Otaegui, D.; Lawrie, C.H. The circulating transcriptome as a source of non-invasive cancer biomarkers: Concepts and controversies of non-coding and coding RNA in body fluids. J. Cell. Mol. Med. 2015, 19, 2307-2323. [CrossRef] [PubMed]

112. Rupaimoole, R.; Slack, F.J. MicroRNA therapeutics: Towards a new era for the management of cancer and other diseases. Nat. Reviews. Drug Discov. 2017, 16, 203-222. [CrossRef] [PubMed]

113. Hanna, J.; Hossain, G.S.; Kocerha, J. The Potential for microRNA Therapeutics and Clinical Research. Front. Genet. 2019, 10, 478. [CrossRef] [PubMed]

114. Chakraborty, C.; Sharma, A.R.; Sharma, G.; Lee, S.S. Therapeutic advances of miRNAs: A preclinical and clinical update. J. Adv. Res. 2021, 28, 127-138. [CrossRef] [PubMed]

115. Liu, Y.P.; Vink, M.A.; Westerink, J.T.; Ramirez de Arellano, E.; Konstantinova, P.; Ter Brake, O.; Berkhout, B. Titers of lentiviral vectors encoding shRNAs and miRNAs are reduced by different mechanisms that require distinct repair strategies. RNA (N. Y.) 2010, 10, 1328-1339. [CrossRef]

116. Collins, S.A.; Guinn, B.A.; Harrison, P.T.; Scallan, M.F.; O'Sullivan, G.C.; Tangney, M. Viral vectors in cancer immunotherapy: Which vector for which strategy? Curr. Gene Ther. 2008, 8, 66-78. [CrossRef] [PubMed]

117. Ganju, A.; Khan, S.; Hafeez, B.B.; Behrman, S.W.; Yallapu, M.M.; Chauhan, S.C.; Jaggi, M. miRNA nanotherapeutics for cancer. Drug Discov. Today 2017, 22, 424-432. [CrossRef]

118. Boca, S.; Gulei, D.; Zimta, A.A.; Onaciu, A.; Magdo, L.; Tigu, A.B.; Ionescu, C.; Irimie, A.; Buiga, R.; Berindan-Neagoe, I. Nanoscale delivery systems for microRNAs in cancer therapy. Cell. Mol. Life Sci. 2020, 77, 1059-1086. [CrossRef]

119. Reid, G.; Pel, M.E.; Kirschner, M.B.; Cheng, Y.Y.; Mugridge, N.; Weiss, J.; Williams, M.; Wright, C.; Edelman, J.J.; Vallely, M.P.; et al. Restoring expression of miR-16: A novel approach to therapy for malignant pleural mesothelioma. Ann. Oncol. Off. J. Eur. Soc. Med Oncol. 2013, 24, 3128-3135. [CrossRef]

120. Hong, D.S.; Kang, Y.K.; Borad, M.; Sachdev, J.; Ejadi, S.; Lim, H.Y.; Brenner, A.J.; Park, K.; Lee, J.L.; Kim, T.Y.; et al. Phase 1 study of MRX34, a liposomal miR-34a mimic, in patients with advanced solid tumours. Br. J. Cancer 2020, 122, 1630-1637. [CrossRef]

121. Seto, A.G.; Beatty, X.; Lynch, J.M.; Hermreck, M.; Tetzlaff, M.; Duvic, M.; Jackson, A.L. Cobomarsen, an oligonucleotide inhibitor of miR-155, co-ordinately regulates multiple survival pathways to reduce cellular proliferation and survival in cutaneous T-cell lymphoma. Br. J. Haematol. 2018, 183, 428-444. [CrossRef] [PubMed]

122. Im, E.J.; Lee, C.H.; Moon, P.G.; Rangaswamy, G.G.; Lee, B.; Lee, J.M.; Lee, J.C.; Jee, J.G.; Bae, J.S.; Kwon, T.K.; et al. Sulfisoxazole inhibits the secretion of small extracellular vesicles by targeting the endothelin receptor A. Nat. Commun. 2019, 10, 1387. [CrossRef]

123. Datta, A.; Kim, H.; Lal, M.; McGee, L.; Johnson, A.; Moustafa, A.A.; Jones, J.C.; Mondal, D.; Ferrer, M.; Abdel-Mageed, A.B. Manumycin A suppresses exosome biogenesis and secretion via targeted inhibition of Ras/Raf/ERK1/2 signaling and hnRNP $\mathrm{H} 1$ in castration-resistant prostate cancer cells. Cancer Lett. 2017, 408, 73-81. [CrossRef] [PubMed]

124. Nishida-Aoki, N.; Tominaga, N.; Takeshita, F.; Sonoda, H.; Yoshioka, Y.; Ochiya, T. Disruption of Circulating Extracellular Vesicles as a Novel Therapeutic Strategy against Cancer Metastasis. Mol. Ther. J. Am. Soc. Gene Ther. 2017, 25, 181-191. [CrossRef]

125. Ortiz, A.; Gui, J.; Zahedi, F.; Yu, P.; Cho, C.; Bhattacharya, S.; Carbone, C.J.; Yu, Q.; Katlinski, K.V.; Katlinskaya, Y.V.; et al. An Interferon-Driven Oxysterol-Based Defense against Tumor-Derived Extracellular Vesicles. Cancer Cell 2019, 35, 33-45.e6. [CrossRef] [PubMed] 